Економічні науки: збірник наукових праць Луцького національного технічного університету. Серія "Регіональна економіка". Випуск 18 (71). Редкол.: відп. ред. д.е.н., професор Л.Л. Ковальська. Луцьк: ІВВ Луцького НТУ, 2021. 278 с.

УДК 657

Ткачук I.М., к.е.н, доцент

Луцький національний технічний університет

\title{
АКТУАЛЬНІ ПИТАННЯ ПОБУДОВИ ВНУТРІШНЬОГО КОНТРОЛЮ ЗОВНІШНЬОЕКОНОМІЧНОЇ ДІЯЛЬНОСТІ НА ПІДПРИЄМСТВІ
}

У статті висвітлено актуальні питання притаманні процесу організації внутрішнього контролю зовнішньоекономічної діяльності на підприємстві. Як відомо, система внутрішнього контролю зовнішньоекономічної діяльності необхідна щоб забезпечити впевненість власників у тому, що покладені на керівництво підприємства завдання та обов'язки виконуються вчасно та на належному рівні. В процесі дослідження розглянуто та проаналізовано фактори, що впливають ефективність впровадження внутрішнього контролю зовнішньоекономічної діяльності на підприємстві. Обгрунтовано, що внутрішній контроль зовнішньоекономічної діяльності, який здійснюється бухгалтером включає в себе перевірку законності та достовірності господарських операцій, вивчення результатів зовнішньоекономічної операцій в цілому.

Ключові слова: внутрішній контроль, зовнішньоекономічна діяльність, інформаційне забезпечення, управлінські рішення, відповідальна особа.

\section{Tkachuk I.}

\section{CURRENT ISSUES OF CONSTRUCTION OF INTERNAL CONTROL OF FOREIGN ECONOMIC ACTIVITY AT THE ENTERPRISE}

The article highlights current issues inherent in the process of organizing internal control of foreign economic activity at the enterprise. As you know, in order to avoid violations of the law, an effective and efficient tool for management staff is internal control. That is why the system of internal control of foreign economic activity is necessary to ensure the confidence of the owners that the tasks and responsibilities assigned to the management of the enterprise are performed on time and at the appropriate level. Of course, control does not exist in itself, it is significantly influenced by the owner, the person authorized by him and the staff. In the course of research the factors influencing efficiency of introduction of internal control of foreign economic activity at the enterprise are considered and analyzed.

It is substantiated that the internal control of foreign economic activity, which is carried out by the accountant, includes checking the legality and reliability 
Економічні науки: збірник наукових праць Луцького національного технічного університету. Серія "Регіональна економіка". Випуск 18 (71). Редкол.: відп. ред. д.е.н., професор Л.Л. Ковальська. Луцьк: ІВВ Луцького НТУ, 2021. 278 с.

of business transactions, studying the results of foreign economic transactions in general. It is established that the construction of the system of internal control of foreign economic activity is influenced by a number of factors: the form of the business entity, its structure, types of activity; the attitude of the owner and the authorized person to the internal control, its purpose and mechanism; level of information support and computerization of activity; availability of financial resources for control.

Key words: internal control, foreign economic activity, information support, management decisions, responsible person.

Ткачук И.Н.

\section{АКТУАЛЬНЫЕ ВОПРОСЫ ПОСТРОЕНИЯ ВНУТРЕННЕГО КОНТРОЛЯ ВНЕШНЕЭКОНОМИЧЕСКОЙ ДЕЯТЕЛЬНОСТИ НА ПРЕДПРИЯТИИ}

В статье освещены актуальные вопросы присущи процессу организации внутреннего контроля внешнеэкономической деятельности на предприятии. Как известно, система внутреннего контроля внешнеэкономической деятельности необходима чтобы обеспечить уверенность владельцев в том, что возложенные на руководство предприятия задачи и обязанности выполняются вовремя и на должном уровне. В процессе исследования рассмотрены и проанализированы факторы, влияющие на эффективность внедрения внутреннего контроля внешнеэкономической деятельности на предприятии. Обосновано, что внутренний контроль внешнеэкономической деятельности, осуществляется бухгалтером включает в себя проверку законности и достоверности хозяйственных операций, изучение результатов внешнеэкономической операций в целом.

Ключевые слова: внутренний контроль, внешнеэкономическая деятельность, информационное обеспечение, управленческие решения, ответственное лицо.

Постановка проблеми у загальному вигляді та ії зв'язок 3 важливими науковими та практичними завданнями. 3 метою прийняття ефективних управлінських рішень кожен суб'єкт господарювання здійснює внутрішній контроль господарської та фінансової діяльності. $\mathrm{He} \epsilon$ виключенням в даному випадку зовнішньоекономічна діяльність (надалі - ЗЕД) підприємства і питання, які включаються до процесу внутрішнього контролю залежать від обсягів ЗЕД та відповідальних осіб. 
Економічні науки: збірник наукових праць Луцького національного технічного університету. Серія "Регіональна економіка". Випуск 18 (71). Редкол.: відп. ред. д.е.н., професор Л.Л. Ковальська. Луиьк: ІВВ Луиького НТУ, 2021. 278 с.

Важливе місце у зовнішньоекономічній діяльності підприємства має відводить саме внутрішньому контролю, який забезпечує перевірку належного виконання поставлених цілей всіма підрозділами або відповідальними особами. І як відмічено Гоголь Т.А. та Маргасовою В.Г. «ефективність системи внутрішнього контролю залежить від його місця в організаційній структурі підприємства. Найчастіше в системі управління діяльністю малого підприємства внутрішній контроль покладено на керівника або на головного бухгалтера» [3].

Необхідність впровадження підприємством внутрішнього контролю ЗЕД розкрито у дослідженні Кінзерської Н.В. Автором особлива увага приділена питанням методичного забезпечення ЗЕД, зокрема «реалізація завдань системи внутрішнього контролю ЗЕД в умовах ризику забезпечується шляхом формування належного методичного забезпечення та механізмів контролю, які забезпечать ефективне здійснення бізнес-процесів в сфері ЗЕД» [6].

В ідеалі внутрішній контроль зовнішньоекономічної діяльності представляє собою безперервний процес відстеження іiі ефективності та доцільності, виявлення негативних моментів та своєчасне ї усунення, визначення та застосування внутрішніх резервів, оцінку досягнення поставлених цілей 3 урахуванням понесених відповідних витрат.

Аналіз останніх досліджень, у яких започатковано вирішення проблеми. Питання необхідності запровадження внутрішнього контролю, механізм його застосування розкривається у дослідженнях багатьох вчених та практиків. Так, про актуальність та необхідність внутрішнього контролю на підприємстві розкрито у працях таких авторів: Гевчук А.В. [1], Гоголь Т.А., Маргасова В.Г. [3], Михалків А.А., Косташ Т.В.[5], Дайновський Ю.А. [4] та ін. Питання внутрішнього контролю зовнішньоекономічної діяльності висвітлено у досліджені Кінзерської Н.В. [6], Глущенко Я.І. [2].

Результати представлених науковцями досліджень свідчать про необхідність удосконалення системи внутрішнього 
Економічні науки: збірник наукових праць Луцького національного технічного університету. Серія "Регіональна економіка". Випуск 18 (71). Редкол.: відп. ред. д.е.н., професор Л.Л. Ковальська. Луиьк: ІВВ Луиького НТУ, 2021. 278 с.

контролю, з урахуванням особливостей діяльності підприємства та вимог сьогодення щодо інформатизації процесу ЗЕД.

Метою статті є дослідження актуальних питань щодо побудови внутрішнього контролю зовнішньоекономічної діяльності на підприємстві.

Виклад основного матеріалу дослідження 3 повним обгрунтуванням отриманих наукових результатів. Дослідження науковців та практиків свідчить, що внутрішній контроль поширюється на всю систему управління підприємством і відповідно, потребує ефективної організації. Як підмічено Гевчук А.В. «контроль являє собою сукупність дій i операцій, здійснюваних спеціально уповноваженими органами, 3 метою контролю за дотриманням суб'єктами господарювання норм права в процесі створення, розподілу і використання фінансових ресурсів для своєчасного отримання повної i достовірної інформації про хід реалізації прийнятих управлінських і фінансових рішень» [1]. Відносно необхідності функціонування системи внутрішнього контролю, актуальною є думка Михалків А.А. та Косташ Т.В., що «створення і розвиток системи внутрішнього контролю $є$ одним 3 основних умов становлення правових відносин на підприємстві» [5].

Варто відмітити, що проведення внутрішнього контролю на належному рівні забезпечує готовність суб'єкта господарювання до контролю зовнішнього. Так, процес зовнішньоекономічної діяльності є об'єктом для контролю зі сторони контролюючих органів. При цьому, на противагу внутрішньому контролю, за результатами зовнішнього контролю ЗЕД відповідальні особи притягаються до фінансової, адміністративної та кримінальної відповідальності.

I так, плануючи впровадження внутрішнього контролю ЗЕД, суб'єкт господарювання має визначити для себе головні його етапи побудови (рис. 1). 
Економічні науки: збірник наукових праць Луцького національного технічного університету. Серія "Регіональна економіка". Випуск 18 (71). Редкол.: відп. ред. д.е.н., професор Л.Л. Ковальська. Луиьк: ІВВ Луиького НТУ, 2021. 278 с.

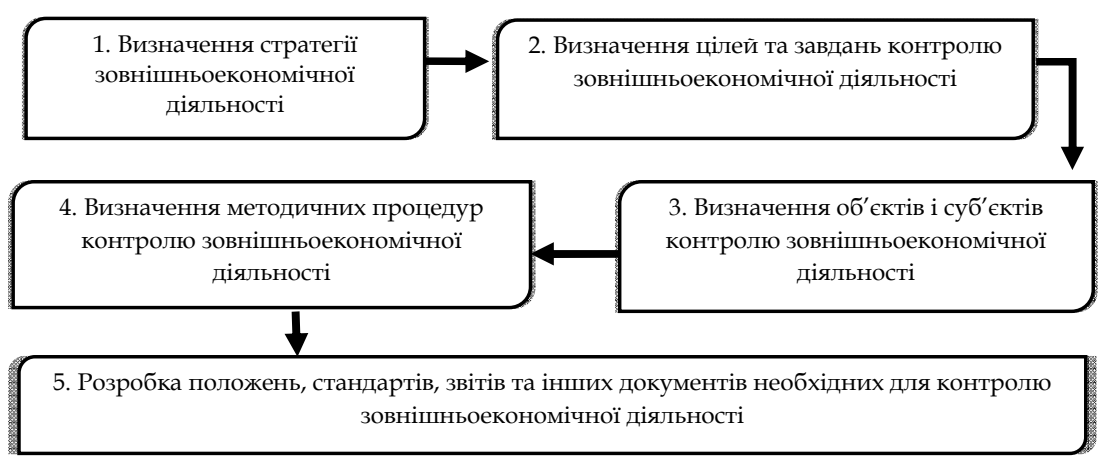

Рис. 1. Послідовність впровадження внутрішнього контролю ЗЕД

Джерело: сформовано автором

Узагальнюючи вище зазначене визначено, що основною метою здійснення внутрішнього контролю ЗЕД є забезпечення успішної діяльності суб'єкта господарювання. Визначити завдання контролю зобов'язані власник або уповноважена ним особа. За даними сформованих завдань визначаються об'єкти, які підлягають контролю та суб'єкти, які є відповідальними за проведення контролю та його ефективність. Як саме проводити контроль і за допомогою якого методичного інструментарію узгоджується суб' єктами контролю.

В даному випадку, заслуговує на увагу підхід Дайновського Ю.А. стосовно використання методів задля зростання ефективності системи внутрішнього контролю, а саме: «метод розподілу повноважень і відповідальності між працівниками, ротація кадрів, здійснення контролю за окремими напрямами діяльності, вдосконалення контролю при плануванні продажу, збору інформації та формування справи-досьє на покупців і замовників, діагностики і прогнозування проблем» [4].

Побудова внутрішнього контролю зовнішньоекономічної діяльності знаходиться під впливом низки факторів (рис. 2). 
Економічні науки: збірник наукових праць Луцького національного технічного університету. Серія "Регіональна економіка". Випуск 18 (71). Редкол.: відп. ред. д.е.н., професор Л.Л. Ковальська. Луиьк: ІВВ Луиького НТУ, 2021. 278 с.

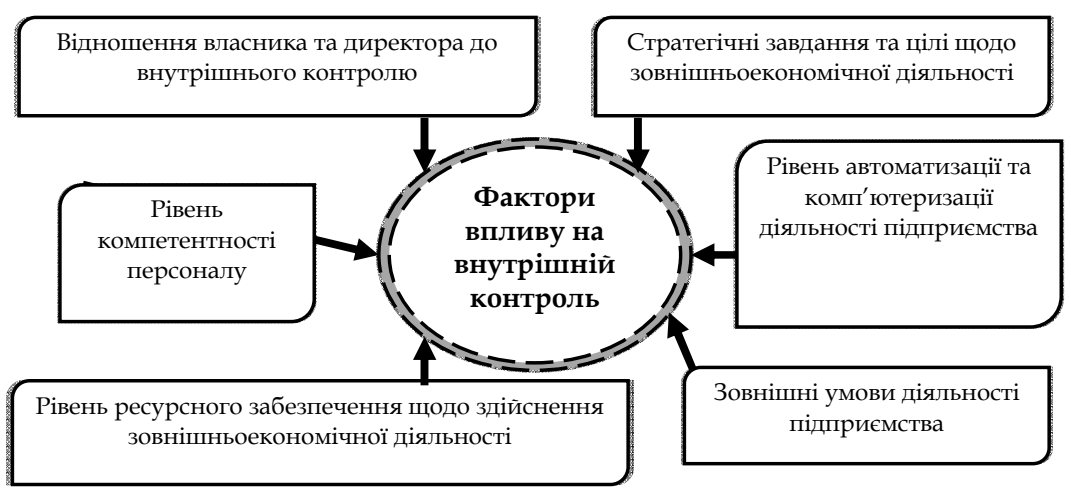

Рис. 2. Фактори, що впливають на побудову внутрішнього контролю ЗЕД

Джерело: сформовано автором

Вирішальне значення в процесі побудову внутрішнього контролю ЗЕД має відношення до нього власника або уповноваженої ним особи, тобто на скільки керівництвом визнається необхідність контролю та його роль в діяльності підприємства. На практиці питання здійснення внутрішнього контролю в цілому належить до повноважень власника або уповноваженої ним особи (директора). Контроль, що проводиться власником або директором забезпечує перевірку достовірності інформації, яка надходить та впливає на прийняття управлінських рішень.

Проведення внутрішнього контролю регламентується внутрішніми документами та здійснюється, як вибірково так i суцільно за зовнішньоекономічними операціями.

Раціональність і доцільність організації внутрішнього контролю ЗЕД визначається якістю інформаційного забезпечення. Документальний контроль зовнішньоекономічної діяльності проводиться за допомогою нормативно-правової перевірки, логічної та арифметичної перевірки, зустрічної звірки, логічної перевірки.

Важливою складовою ефективності контролю зовнішньоекономічної діяльності $€$ якість інформаційного 
Економічні науки: збірник наукових праць Луцького національного технічного університету. Серія "Регіональна економіка". Випуск 18 (71). Редкол.: відп. ред. д.е.н., професор Л.Л. Ковальська. Луиьк: ІВВ Луиького НТУ, 2021. 278 с.

забезпечення, тобто своєчасна, достовірна та оперативна інформація. До основних інформаційних джерел, які використовуються в процесі контролі ЗЕД, відносять:

1. Законодавчо-нормативні акти, які регламентують принципи обліку ЗЕД.

2. Внутрішні організаційно-методичні документи, якими закріплено правила здійснення зовнішньоекономічних операцій з урахуванням їх специфіки.

3. Первинні документи та зведені реєстри в яких міститься інформація про зовнішньоекономічні операції.

4. Зовнішні та внутрішні форми звітності.

Вагомою перевагою проведення внутрішнього контролю ЗЕД $\epsilon$ його часовий інтервал. Зокрема, контроль може здійснюватися, як попередній, поточний (оперативний) та наступний. В свою чергу Глущенко Я.І. відмічено, що «виокремлення попереднього, поточного та наступного контролю, визначення інформаційно-організаційних та методичних аспектів дозволяє удосконалити регламентне забезпечення внутрішнього контролю, більш оптимально розподілити функціональні обов'язки працівників й уникнути їх подвоювання» [2].

Попередній контроль зовнішньоекономічної діяльності проводять власник або уповноважена ним особа, а також бухгалтер. Особливість попереднього контролю - здійснення на всіх рівнях управління, а також можливість проведення його до моменту прийняття остаточного управлінського рішення або здійснення господарської операції у ЗЕД. Проводиться попередній контроль ЗЕД 3 метою уникнення незаконних господарських операцій та забезпечення ефективного використання ресурсів підприємства.

Призначення поточного (оперативного) контролю виявити недоліки у процесі проведення ЗЕД, які неможливо було виявити при попередньому контролі, а також виявити можливі резерви. У процесі поточного контролю особливу увагу господарським операціям приділяє персонал, який зацікавлений в прийнятті управлінських рішень. 
Економічні науки: збірник наукових праць Луцького національного технічного університету. Серія "Регіональна економіка". Випуск 18 (71). Редкол.: відп. ред. д.е.н., професор Л.Л. Ковальська. Луиьк: ІВВ Луиького НТУ, 2021. 278 с.

Відмітимо, що поєднання попереднього i поточного контролю ЗЕД надає можливість попередити непередбачені втрати матеріальних та фінансових ресурсів.

Підгрунтям для проведення наступного контролю $\epsilon$ інформація зафіксована у бухгалтерській документації та здійснюється він після завершення зовнішньоекономічних операцій. Необхідність здійснення наступного контролю ЗЕД зумовлена визначенням законності та доцільності проведених операцій, виявленням порушень, зловживань та недоліків. Своєчасна оцінка здійсненних зовнішньоекономічних операцій забезпечує ефективність прийнятих у подальшому управлінських рішень.

Оптимальним та найбільш дієвим внутрішній контроль ЗЕД $є$ у випадку поєднання попереднього, поточного та наступного контролю. Досягнути такого поєднання вдається не всім суб'єктам господарювання, а лише тим в яких чітко налагоджена система внутрішнього контролю.

Висновки. Внутрішній контроль присутній в усіх суб'єктів господарювання, які здійснюють ЗЕД, адже ними проводиться контроль своєчасності оплати та поставки, оцінка отриманих доходів і понесених витрат, а також фінансовий результат від зовнішньоекономічних операцій. Важливо відмітити, що завдання та мета внутрішнього контролю ЗЕД повинні бути узгоджені та відповідати визначеній стратегії розвитку підприємства. До тогож, цифрові трансформації вимагають нового бачення та мислення щодо процесу здійснення внутрішнього контролю.

\section{Список бібліографічного опису}

1.Гевчук А.В. Внутрішній контроль обліку розрахункових операцій на підприємстві. Вчені записки університету «КРОК». Серія : Економіка. 2019. Вип. 2. С. 72-79.

2.Глущенко Я.І. Внутрішній контроль зовнішньоекономічного договору: інформаційно-організаційні та методичні аспекти. Причорноморські економічні студії. 2017. Вип. 16. С. 64-68. URL: http://bses.in.ua/journals/2017/16_2017/16.pdf

3.Гоголь Т.А., Маргасова В.Г. Організація управлінського обліку і контролю на підприємствах малого бізнесу. Вісник ХНАУ. Серія : Економічні науки. 2018. № 2. С. 401-411. 
Економічні науки: збірник наукових праць Луцького національного технічного університету. Серія "Регіональна економіка". Випуск 18 (71). Редкол.: відп. ред. д.е.н., професор Л.Л. Ковальська. Луцьк: ІВВ Луцького НТУ, 2021. 278 с.

4.Дайновський Ю.А. Внутрішній контроль в управлінні діяльністю підприємств: сутність, значення. Вісник Львівської комерційної академії. Серія економічна. 2016. Вип. 50. С. 105-109.

5.Михалків А.А., Косташ Т.В. Внутрішній контроль процесу господарювання: проблеми організації. Економіка та держава. 2020. № 1. C. 61-65. URL: http://www.economy.in.ua/pdf/1_2020/13.pdf

6.Кінзерська Н.В. Методичне забезпечення внутрішнього контролю зовнішньоекономічної діяльності підприємств торгівлі. Економіка та суспільство. 2021 Вип. $27 . \quad$ URL: https://economyandsociety.in.ua/index.php/journal/article/view/442/424

\section{References}

1.Hevchuk A.V. Vnutrishniy kontrol' obliku rozrakhunkovykh operatsiy na pidpryyemstvi. Vcheni zapysky universytetu «KROK». Seriya : Ekonomika. 2019. Vyp. 2. S. 72-79.

2.Hlushchenko Ya.I. Vnutrishniy kontrol' zovnishn'oekonomichnoho dohovoru: informatsiyno-orhanizatsiyni ta metodychni aspekty. Prychornomors'ki ekonomichni studiyi. 2017. Vyp. 16. S. 64-68. URL: http://bses.in.ua/journals/2017/16_2017/16.pdf

3.Hohol' T.A., Marhasova V.H. Orhanizatsiya upravlins'koho obliku i kontrolyu na pidpryyemstvakh maloho biznesu. Visnyk KhNAU. Seriya : Ekonomichni nauky. 2018. \# 2. S. 401-411.

4.Daynovs'kyy Yu.A. Vnutrishniy kontrol' v upravlinni diyal'nistyu pidpryyemstv: sutnist', znachennya. Visnyk L'vivs'koyi komertsiynoyi akademiyi. Seriya ekonomichna. 2016. Vyp. 50. S. 105-109.

5.Mykhalkiv A.A., Kostash T.V. Vnutrishniy kontrol' protsesu hospodaryuvannya: problemy orhanizatsiyi. Ekonomika ta derzhava. 2020. \# 1 . S. 61-65. URL: http://www.economy.in.ua/pdf/1_2020/13.pdf

6.Kinzers'ka N.V. Metodychne zabezpechennya vnutrishn'oho kontrolyu zovnishn'oekonomichnoyi diyal'nosti pidpryyemstv torhivli. Ekonomika ta $\begin{array}{llll}\text { suspil'stvo. } & 2021 & \text { Vyp. } & \text { URL: }\end{array}$ https://economyandsociety.in.ua/index.php/journal/article/view/442/424

DOI: https://doi.org/10.36910/2707-6296-2021-18(71)-23 